\title{
Az EU tagállamok innovációs és versenyképességi klaszteresedése 2013-ban
}

\author{
BALDA GÁBOR ${ }^{1}$
}

\begin{abstract}
ABSZTRAKT
Az innovációs gazdaság korában érthető módon az innováció központi jelentőségú fogalomként jelenik meg, amelynek irodalma ezért rendkívül szerteágazó: globális, makro-és mikro-szinten, az üzleti és non-business szektor kapcsán, sőt társadalmi vonatkozásban is értelmezik. Jelen írás irodalmi háttere egy történeti áttekintést mutat be az innováció fogalomkörének fejlődéséről, és annak különböző értelmezéseiről.

Az irodalmi háttér feltárása után kvantitatív, leíró és magyarázó jellegú statisztikai adatelemzés került leírásra, monotetikus, és deduktív megközelítésben. Kutatásom jelenlegi fázisában makroszintü nemzetközi összehasonlító elemzéseket végzek az EU és a WEF (World Economic Forum) adatbázisán (Innovation Union Scoreboard, illetve Global Competitiveness Index), az SPSS adatbázis kezelő szoftver segítségével. Jelen kutatás célja, hogy választ találjon arra, az innovációs folyamatok, és a versenyképesség alakulása között makroszinten van-e kapcsolat, és ha van, az miként értelmezhetö. A későbbiekben hasonló céllal és metodikával nemzetközi mikro-szintü összehasonlító elemzéseket kívánok végezni, majd a makro- és mikro-szintü eredmények összevetésével választ keresni arra, hogy a makro-szintü innovációs politika hogyan befolyásolja a mikro-szintü innovativitást és versenyképességet. Mindezek alapján pedig meghatározni kívánom a hazai innovációs politika sajátos vonásait, optimalizálásának lehetőségeit.

KULCSSZAVAK: innováció, versenyképesség, Európai Unió, fökomponens elemzés, klaszterelemzés, differenciáltság
\end{abstract}

\section{ABSTRACT}

\section{The EU states innovation and competitiveness clusters in 2013}

In the era of the innovation economy it is natural that innovation is one of the key definitions, because of its literature is excessively far-reaching: global, micro and macro level, in connection of the business and non-business sector, it's also defined in social context. The literary background of this essay shows a historical overview of the development that occurred in the definition of innovation and its different interpretations.

\footnotetext{
${ }^{1}$ Egyetemi óraadó, Szegedi Tudományegyetem Gazdaságtudományi Kar.
} 


\section{TEMATIKUS TANULMÁNYOK - Menedzsment: vezetők, vezetés és munkavállalók}

After exploring the literary background a quantitative, descriptive and explanatory statistic analysis will be written in a monothetic and deductive approach. In this phase of my research I will make macro level international comparative analyzes with the help of the EU and the WEF (World Economic Forum) data base (Innovation Union Scoreboard, illetve Global Competitiveness Index), and the SPSS software. This essay's goal is to determine whether there is a connection between innovation processes and the forming of competitiveness on a macro level and if there is how it can be interpreted. Later with a similar goal and methodology I would like to make international micro level comparative analyzes and then by combining the macro and micro level results, I will determine how the macro level innovation policy influences the micro level innovativeness and competitiveness. Using all of these results I would like to determine the special features of the national innovation policy and the chances for optimalization.

KEYWORDS: innovation, competitiveness, European Union, principal component analysis, cluster analysis, differentiation

\section{Bevezetés}

Az innovációs gazdaság korában érthető módon az innováció központi jelentőségű fogalomként jelenik meg, amelynek irodalma ezért rendkívül szerteágazó: globális, makro- és mikro-szinten, az üzleti és non-business szektor kapcsán, sőt társadalmi vonatkozásban is értelmezik. Jelen írás irodalmi háttere egy történeti áttekintést mutat be az innováció fogalomkörének fejlődéséről, és annak különböző értelmezéseiről. Ennek az áttekintésnek egyik célja, hogy világossá váljon a kutatásom egyik alapvető fogalmának sokszínű értelmezése, amely miatt jómagamnak is definiálnom kell, hogy értelmezésemben mit jelent az innováció.

A szakirodalmi áttekintés után az Innovation Union Scoreboard (IUS) és Global Competitiveness Index (GCI) 2013-as évre vonatkozó adatbázisának felhasználásával az Európai Unió tagállamait vizsgáltam. Célom az volt, hogy kapcsolatot találjak az innováció, és a versenyképesség között. Jelen kutatás leíró, és magyarázó jellegű, monotetikus, és deduktív megközelítéssel.

Kutatási kérdés:

Az Európai Unió tagállamainak mezőnyében makro-szinten milyen a kölcsönhatás az innováció és a versenyképesség között?

\section{Az innováció modernkori értelmezésének gazdaságtudományi megközelítése}

Az emberi fejlődés innovációk végtelen sorozatát jelenti, amely éppen a 21 . században ért a tetőpontjára, egyben a fordulópontjára is, ahogyan arra a technológiai fejlődés előrejelzésével foglalkozó szakértők, például Ray Kurzweil és sokan mások 


\section{TEMATIKUS TANULMÁNYOK - Menedzsment: vezetők, vezetés és munkavállalók}

rámutatnak, amikor az ún. szingularitás 2045-2050 táján nagy valószínűséggel bekövetkezik (Gerdesics - Pavluska 2013). A fogalom modernkori definícióját Schumpeter adta meg először, aki úttörő módon beszélt a megújításról, megteremtve számos kutató munkásságának alapját. Az általa lefektetett alapokat azóta tovább bővítették, mára számos tudomány, sokszor eltérő értelmezésben használja. A kor tudósa még nem használta magát az innováció kifejezést, a fogalom tartamát azonban igen.

A kutatók legtöbbje az ehhez kapcsolódó fogalomrendszeren belül megkülönbözteti az invention, azaz feltalálás, illetve az innováció, azaz megújítás kifejezéseket. Peter F. Drucker legszűkebb halmazként a feltalálást definiálja, melyet ugyan magába foglal az innováció fogalma, de maga a megújítás kifejezés már szélesebb aspektusban értelmezendő. Drucker megkülönböztet originális, azaz saját eredményen alapuló innovációt, és adaptívat, azaz más szervezettől átvettet (Drucker 1985). A szakirodalmak legtöbbje szerint azonban az innováció megléte nem elégséges, annak diffúzióját, azaz elterjedését is tárgyalni kell. A kutatók alapvetően egyetértenek ebben, inkább azt egy-egy tudományos terület más-más árnyalatokkal értelmezi.

Az innovációt számos tudományágban eltérő fázisokra osztják, és egy-egy tudományágra sem jellemző még az egységes fogalmi „mainstream”. Mielőtt kitekintést nyújtanék a különböző gazdasági tudományos értelmezésekre, tekintsük át Schumpeter innovációs értelmezését.

Az innováció Schumpeter-i tagolása:

\section{Termék- és szolgáltatás-innováció}

Schumpeter ebben a kategóriában olyan új termékek, vagy szolgáltatások bevezetését értelmezi, amelyek a fogyasztói társadalomban újdonságnak számítanak (Schumpeter 1943).

\section{Folyamat-innováció}

Az új termékek előállítása, illetve az új szolgáltatások nyújtásának körülményei új eljárásokat, újszerü folyamatok bevezetését igényelték a gazdaságban (Schumpeter 1943).

\section{Piaci innováció}

Az eljárások korszerűsödése, és az újfajta gyártási apparátusok kiépülései, több termék megtermelését hozták. A felvevőpiac bár növekedhetett az újdonságokkal együtt, de sok esetben a kereslet növekedése sajnos elmaradt a kínálat növekedésétől. A túlkínálat új piacok keresését igényelte, ez pedig a piacra vonatkozó innovációk széles tárházát hozta (Schumpeter 1943).

\section{Beszerzési innováció}

A gyártási kapacitások, és a piaci innovációk nyomán megnőtt az igény a vállalatok input felhasználásának bővülése iránt. A nyersanyagok, vagy a vállalati láncszemek által gyártott félkész termékek beszerzése így számos innovációt hozott (Schumpeter 1943). 


\section{TEMATIKUS TANULMÁNYOK - Menedzsment: vezetők, vezetés és munkavállalók}

\section{Szervezeti innováció}

Az átalakult feltételek másfajta dolgozói apparátust igényeltek, másfajta vezetési felfogással. Új szervezetek formálódtak, az iparágak újraszerveződtek, és szintén átalakultak. A vezetői szemléletek megváltoztak. A menedzser réteg megjelenése számos új vezetési stratégiát hozott a vállalatok világában, amivel a gazdasági értelemben vett vállalatvezetés fordulatot vett (Schumpeter 1943).

A gazdaságtudományok egyik kiemelkedő irányzata Peter F. Drucker innovációs fogalomköre alapján fogalmazódott meg, az innovációt lényegében egyfajta társadalmi, közösségi, és családi igényre adott válasznak tekinti (Drucker 1985). Varga értelmezésében a változások menedzselése, és a versenytársakhoz való alkalmazkodás szintén fontos a változáshoz, azonban a Schumpeter-i kreatív rombolás értelmében először rombolni kell az építkezéshez (Varga 2015).

Számos tudományos kutatás pusztán az innovációs és versenyképességi teljesítmény kapcsolatára szorítkozik. Az innováció helyzetét sok esetben a nemzetgazdaságok teljesítményével hozzák összhangba, és ezeket az újításokat sokszor a nemzetgazdaságokra gyakorolt hatással magyarázzák. Varga és számos más kutató szerint is, a nemzetgazdaságok fejlettségét, és versenyképességét ezáltal maga az innovációs mérték határozza meg (Varga 2015). Az IMD (World Competitiveness Report), az Európai Bizottság kutatásai (Innovation Union Scoreboard) vagy például a WIPO (Global Innovation Index), World Economic Forum (The Global Competitiveness Report) és Legatum Institute (The Prosperitiy Report), illetve az INSEAD. Mind-mind ezeket a hatásokat próbálják kutatásaikkal alátámasztani.

Dinya László és néhány más, vállalkozásokra vonatkozó kutató a beruházási kockázatot, és a szokások változását vizsgálja. Ezen elméleteknél szintén fontos az innováció a versenyben maradáshoz, és a piaci rész növeléséhez, azonban ezek a filozófiák sokkal inkább arra a kérdésre keresik a választ, hogy milyen területeken van lehetőség változásra, és hol lehet új értékeket teremteni (Dinya 2015a, Dinya 2015b).

Ahhoz, hogy nagy léptékben megérthessük az innovációs folyamatokat, érdemes részletezni az innováció születését. Drucker megkülönbözteti a feltalálást, ami magát az új dolog megalkotását jelenti, valamint az innovációt, ami ennek az újdonságnak az implikálását adja, a diffúzió pedig annak elterjedését (Drucker 1985).

A piaci verseny szempontjából tárgyalható Cristensen megközelítése, aki fenntartó és megszakító innovációk halmazát különíti el. Az új dimenziókban működtetett vállalat piacvezetővé válását fenntartó innovációnak tekinti, amiben a vállalat piacvezetővé válik és helyét folyamatos, újabb innovációkkal őrzi meg (Cristensen 2012). A megszakító innováció esetében az innováció már más célcsoportokat részesít előnyben, ebben az esetben a termék gyártását megváltoztatja az adott vállalat (Cristensen 2012). 


\section{TEMATIKUS TANULMÁNYOK - Menedzsment: vezetők, vezetés és munkavállalók}

Az innovációs folyamat megértésének következő lépcsőfoka az innovációk diffúziója. Az innováció társadalmi fogadtatása, vagy más szóval diffúziója sokszor nem egyértelmű. Az innováció diffúziójának témakörével először Gabriel Tarde francia bíró, szociológus, és szociálpszichológus foglalkozott, aki az 1903-as évektől kezdve elsősorban társadalmon belüli innovációs trendkutatással foglalkozott (Tarde, In: Gerdesics - Pavluska 2013). Később Rogers ezeket a Tarde által bevezetett S alakú diffúziós görbéket használta fel, melyek kommunikációs kutatásai alapjául szolgáltak. Rogers négy alapelemet határozott meg az innováció diffúziójaként: az innovációt, a kommunikációs csatornát, az időt, és az adott társadalmi rendszert (Rogers 2013). A kor társadalma szkeptikusan fogadta Rogers megközelítését. Az osztrák, és brit antropológiai iskolák például társadalmak közötti eltérő innovációs szintekkel magyarázták a diffúziót, ezt az értelmezést pedig a kor antropológiai megközelítéseihez igazították (Gerdesics - Pavluska 2013).

Hagerstadt és Brown a keresleti, és a kínálati oldalról vizsgálták az innováció terjedését. Hagerstadt szerint a társadalom dönt arról, hogy befogadja-e az újdonságot, Brown állítása viszont ezzel szemben az volt, hogy ez önmagában még nem elegendő. Hagerstadt szerint az újdonság befogadásához, és elfogadásához szükséges ugyan a társadalom, de nem elégséges hozzá, tárgyalásában a kormányzati politikák, a non-business, és a business szektor épp úgy szükséges elem, mint a társadalom, és ezek a tényezők is szükségesek ahhoz, hogy úgy alakuljanak az innovációs trendek, mint ahogy alakulnak (Hagerstadt, In: Gerdesics - Pavluska 2015, Brown, In: Gerdesics - Pavluska 2015).

Bass 1969-ben matematikai függvényt fejlesztett ki az új termék fogyasztásáról az idő függvényében, amelyet az 1970-es évektől kezdve a tudósok már különböző országokban, különböző diffúziós szinteken is vizsgáltak (Bass, In: Gerdesics - Pavluska 2013).

Számos kutatás készült ezután is a diffúziós elméletekről, ezek tárgyalása viszont már kutatási elképzeléseimhez nem illeszkedik. Célom az innováció mikro-szintű értelmezésének történeti áttekintése volt, melyet a diffúziós elméletek logikája tekintetében megtettem. A leírtak alapján kijelenthető, hogy az innováció a társadalmi és gazdasági tevékenységek végzésének a gyakorlatban alkalmazott relatíve újszerű és a korábbinál hatékonyabb módja. Ebben fontos a társadalomra is gazdaságra egyaránt kiterjedő értelmezés, a gyakorlatban történő alkalmazás (amíg erre nem kerül sor, addig nem beszélhetünk innovációról), a relatív jelleg (adott helyen is időpontban érvényes újszerűség, nem feltétlenül csak a világviszonylatban megjelenő abszolút újdonság), továbbá a korábbinál hatékonyabb megoldás (az újszerűség önmagában jelenthet a korábbinál rosszabb megoldást is). Az innováció diffúzióját a nemzetgazdaságon belül a politikai berendezkedés, az intézményrendszer, a business, és non-business szektor szintén befolyásolja. Ezekre a megfigyelésekre számos nemzetgazdaságok teljesítményével foglalkozó kutatás vonatkozik. Felhasználva 


\section{TEMATIKUS TANULMÁNYOK - Menedzsment: vezetők, vezetés és munkavállalók}

Rogers gondolatait, kijelenthető ugyan, hogy az innovációk különböző mértékben lehetnek jelen egy-egy társadalomban, mégis jól magyarázhatnak innovációs, és versenyképességi változásokat is, ami alapján jól meghatározott klaszterekbe tömöríthetnek nemzetgazdaságokat (Dinya 2015a, Dinya 2015b).

Az innováció saját értelmezése után, most tekintsünk előre. A globalizált világ számos égető problémával küzd, melyet számos módon értelmezhetünk. Egyre erőteljesebb farkastörvények uralkodnak, és aki lemarad, az könnyen ki is maradhat a jövő gazdasági körforgásából. Az előzőekben számos ponton utaltam arra, hogy számos kutató írásában megfigyelhető az innováció, és a versenyképesség egymásra hatása, melyek egyre több szálon futnak egymáshoz. Dinya László írásaiban utalásokat találunk arra, hogy az innováció a versenyképesség tárgyalásában szinte elengedhetetlen, a világ zsugorodásával, és a globális piaci értelmezések térnyerésével pedig a verseny egyre gyorsabb. Tárgyalásában már nem pusztán az üzleti szféra innovációs hatásait lehet vizsgálni innovációs szempontból, kutatásaiban a non-business szektor, azaz a közszféra is megjelenik, ahol utóbbi ugyan másképpen teremt versenyhelyzetet, és másképpen kell megközelíteni a közszféra céljait is, mégis az innovációs eszközök adaptálása, valamint az üzleti szférához való kapcsolódás mára már adott (Dinya 2015a, Dinya 2015b).

Artner egyik, 2014-ben megjelent cikkében a megváltozott gazdasági folyamatok miatt már egyenesen gazdasági, és társadalmi paradigmaváltásról beszél (Artner, In: Dinya 2015a). A recessziós hatások mára már örvényként hatnak a világgazdaságra. Kiss és Kovács munkái alapján az erre adott egyik lehetséges megoldás az üzleti szféra innovációja, melyet a non-business szektorral együtt kell megújítani, mert a business szektor versenyképességére a közszféra is hatással van (Artner, In: Dinya 2015a, Kovács 2014, Kiss 2013).

A paradigmaváltás egyik lehetséges eszköze a „kreatív rombolás”. Ahhoz ugyanis, hogy újra lehessen értelmezni a gazdaságot, és a társadalmat, először újra kell értelmezni közgazdasági értelemben releváns fogalmakat is. A vállalati szektor, a közszféra, és az állami szektor fogalomrendszerét, és az intézmények céljait értelmezni pedig hosszadalmas, és nehézkes feladat (Dinya 2015a, Dinya 2015b).

Előfordulhat ugyanakkor az is, hogy nem történik meg az innováció diffúziója, és ekkor a folyamatot meg kell ismételni mindaddig, amíg el nem érjük az elvárt társadalmi jóléti szintet.

Dinya László éppen ezért érvel amellett, hogy újra kell értelmezni a vállalkozásoknak céljaikat, és új megközelítéseket kell találniuk az üzleti siker definiálásánál. A profit hajszolása helyett jelenleg fontosabb az életben maradás, és a versenyképesség megőrzése. Jóllehet, ez az innovációs hatások ismételt folyamatát teszi szükségessé, de remélhetőleg felfelé ívelő spirált hoz, és nem lefelé húzó örvényt okoz. Csatlakozva ehhez a kutatáshoz, a tanulmány következő részeiben a business, és non-business szektorok innovációs együttállását, nemzetközi összehasonlító vizsgálatokkal kísérlem meg alátámasztani. Számos kutatás létezik, ami a business, és 


\section{TEMATIKUS TANULMÁNYOK - Menedzsment: vezetők, vezetés és munkavállalók}

non-business szektorokat indikátorokba rendezve mérik, ezekre vonatkozóan pedig számos kutatást lehet végezni a fentebb említett innovációs együttmozgásokra vonatkozóan (Dinya 2015a, Dinya 2015b).

Dinya László 2015-ös tanulmányában („Nonbusiness innovációk és versenyképesség"), éppen ezeket az együttállásokat tárgyalja az IUS (Innovation Union Scoreboard) segítségével. Célom az, hogy ezen a nyomon haladva a jövőben ezeket az együtt állásokat jobban megvilágítsam.

Az innováció történeti áttekintései, és a paradigmaváltások lehetséges határain lépkedve az innováció eddig adott definíciói korántsem tekinthetőek még véglegesnek, a jövőben a jelenlegi definíciók könnyen a kreatív rombolás áldozatai lehetnek, mely azonban szükséges lépés lehet az egységes fogalmi keret megalkotásához.

Schumpeter lefektette a modern értelemben vett fogalom kereteit, amely azonban a világ változásával más értelmezést nyer időről időre. Számos kutató, számos megközelítésben és logikus felépítésben értelmezi az innovációt, és hangsúlyozza logikájának helyességét.

Jelen definiálás elismeri az innováció hármas egységét, amely a feltalálás, innováció és annak diffúzióját jelenti, ugyanakkor elfogadja a kreatív rombolás eszméjét is, ami alapján a megújulás néhány esetben hamuból való újjászületést jelenti. Értelmezésemben az innováció nem az üzleti szektorra korlátozott, hanem a non-business szektorral együttműködve létezik. Az innováció egyik fontos mozgatórugója a versenyképességnek, újítást határoz meg vállalati-, nemzetgazdasági-, és nemzetgazdaságok fölötti szinten egyaránt.

Az innováció, tárgyalásomban, részleteiben és egészében együtt értelmezhető, komplex fogalomként értendő. Előrelendít, de mindig az adott helyzethez mérten legoptimálisabbat jelenti, elismerve azt, hogy térben és időben nem lehet általánosítható egy-egy „jó gyakorlat” (Dinya 2015b).

\section{Az EU tagállamok innovációs és versenyképességi klaszteresedése a 2013-as évben}

Jelen kutatás tárgyát az IUS (Innovation Union Scoreboard), és a GCI (Global Competitiveness Index) adatbázisai szolgáltatják. A bemutatásra kerülő többváltozós elemzések alapvetően az innováció, és a versenyképesség kapcsolatára keresik a választ.

\section{Innovation Union Scoreboard - IUS adatbázis}

Az Európai Unióban számos nemzetállamokra vonatkozó felmérést készítenek, a Közösségi Innovációs Felméréseket (CIS, Community Innovation Survey) az EUROSTAT felügyeli. Az első IUS-hez hasonló innovációs kimutatást először 2000-ben közölték 


\section{TEMATIKUS TANULMÁNYOK - Menedzsment: vezetők, vezetés és munkavállalók}

még EIS (Europen Innovation Scoreboard) néven, csak 2010 óta nevezik IUS-nek (Innovation Union Scoreboard). Az IUS adatbázis adatokat szolgáltat az európai térség 34 országára vonatkozóan. 8 kompozit mutatót, és ezen belül 25 innovációs indikátort tartalmaz (IUS 2014)

Az IUS adatbázis 8 kompozit mutatója:

1. kompozit mutató: Humán erőforrás

2. kompozit mutató: Nyitott, kiváló, attraktív kutatási rendszer

3. kompozit mutató: Finanszírozás, támogatás

4. kompozit mutató: Cégek ráfordításai

5. kompozit mutató: Üzleti kapcsolódások

6. kompozit mutató: Szellemi vagyon

7. kompozit mutató: Innovátorok

8. kompozit mutató: Gazdasági hatások

(IUS 2014).

\section{Global Competitiveness Index - GCI adatbázis}

A WEF (World Economic Forum) 2005 óta állít össze versenyképességi indexet a világ országaira vonatkozóan. A Globális Versenyképességi Index GCI (Global Competitiveness Index) a világ 144 országában, 12 kompozit mutatón és 119 versenyképességi indikátoron keresztül készít felméréseket, ahol országonként több ezernyi üzletember megkérdezése alapján gyűjtenek adatokat a versenyképességre vonatkozóan (World Economic Forum 2014).

A GCI adatbázis 12 kompozit mutatója:

1. kompozit mutató: Intézmények

2. kompozit mutató: Infrastruktúra

3. kompozit mutató: Makrogazdasági környezet

4. kompozit mutató: Egészségügy és alapfokú oktatás

5. kompozit mutató: Felsőoktatás és szakképzés

6. kompozit mutató: Árupiaci hatékonyság

7. kompozit mutató: Munkaerő-piaci hatékonyság

8. kompozit mutató: Pénzügyi piacok fejlettsége

9. kompozit mutató: Technológiák fejlettsége

10. kompozit mutató: Piacméret

11. kompozit mutató: Üzleti kifinomultság

12. kompozit mutató: Innováció

(World Economic Forum 2014).

Az adattisztítás során az IUS adatbázis indikátorait jól használhatónak ítéltem meg, pusztán néhány esetben találkoztam hiányzó adatokkal, ezeket a cellákat nul- 


\section{TEMATIKUS TANULMÁNYOK - Menedzsment: vezetők, vezetés és munkavállalók}

lás értékkel töltöttem fel. A GCI adatbázis indikátorai viszont rendkívül széles perspektívában vizsgálnak nemzetgazdaságokat, ezért itt a több, mint 100 indikátorból 81 indikátort ítéltem az elemzés szempontjából relevánsnak (World Economic Forum 2014, IUS 2014).

A két adathalmazt egy adatbázisban egyesítettem a fókomponens-, illetve klaszterelemzésekhez. Az elemzéseket az Európai Unió 24 tagállamára vonatkozóan végeztem el, ami alól speciális gazdasági helyzetük miatt Ciprus, Málta, Luxemburg, és Görögország kivételt képezett.

\subsection{FŐKOMPONENS-ANALÍZIS}

Az SPSS adatbázis kezelő szoftverben összességében 106 indikátorra vonatkozóan végeztem el a főkomponens elemzést. Először megvizsgáltam az indikátorok magyarázóértékét, melyek alapján a 0,5 érték alatti számértékkel bíró indikátorokat kizártam. Ezek alapján az IUS és GCI indikátorai közül 6 innovációs, és 8 versenyképességi mutató esett ki.

A megmaradt 92 indikátor vizsgálatának eredménye 4 főkomponens. Eszerint az első komponens az indikátorok magyarázóerejének közel 31\%-át, a második közel 20\%-át, a harmadik közel 20\%-át, a negyedik pedig közel 9\%-át tartalmazta.

A következő lépésben megvizsgáltam az indikátorok magyarázóértékét. Azokat az indikátorokat, amelyek főkomponensre vonatkozó magyarázóereje 0,65 érték alatti volt, szintén kizártam a kutatásból. Azt tapasztaltam, hogy az első főkomponensben 31 darab indikátor maradt és 15 kiesett, a másodikban 11 indikátor maradt és 8 indikátor esett ki, a harmadikban 12 indikátor maradt és 7 indikátor esett ki, a negyedik főkomponensben pedig 4 indikátor maradt és 4 esett ki.

Az így megmaradt indikátorok a versenyképesség és innováció tekintetében már jól meghatározott főkomponenseket alkottak. Az első és negyedik komponens GCI indikátorokat tartalmazó komponens lett, a második inkább IUS indikátorokat tartalmazó, a harmadik pedig IUS és GCI indikátorokat vegyesen tartalmazó. Az adatok magyarázóerejét figyelembe véve 58 indikátor képezte a következőkben a klaszterek főkomponenseit, 34 indikátor magyarázóereje viszont túl alacsony volt, ezért kiesett az elemzés további fázisából.

\section{Tényezô és hatékonyságvezérelt versenyképességi komponens (I. komponens)}

Az első komponensben versenyképességi mutatók találhatóak. Az indikátorok közül 14 darab az intézmények tényezővezéreltségét magyarázza, vagyis azt, hogy az országban mennyire stabil a politikai intézményrendszer, illetve azt, hogy ezzel menynyire tud együttműködni az adott nemzetgazdaság vállalati apparátusa úgy, hogy mind a vállalati szektor, mind maga a nemzetgazdaság is versenyképes maradjon 


\section{TEMATIKUS TANULMÁNYOK - Menedzsment: vezetők, vezetés és munkavállalók}

nemzetközi szinten. Erre a főkomponensre jellemző a hatékonyságvezéreltség, ami a felsőoktatás és szakképzés, az árupiaci és munkaerő piaci hatékonyság, és a pénzügyi piacok fejlettségét jelenti. Ezt a komponenst ehhez köthetően versenyképességi indikátorok magyarázzák. Az üzleti szofisztikációt, illetve az innováció vezéreltséget innovációs indikátorok magyarázzák. Ez utóbbi a 30-34 év közötti felsőfokú végzettségűek arányát jelenti. Érdekes továbbá, hogy a komponens egyik indikátora, mely az innovációs technológiai hatások szintjét mutatja a versenyképesség szempontjából, szintén ehhez a komponenshez tartozik, ami részletében ugyan, de magyarázza az innováció, és a versenyképesség kapcsolatát.

\section{Versenyképességet támogató innovációs output komponens (II. komponens)}

A második komponenst IUS indikátorok magyarázzák, ezért ez a komponens jellemzően az innovációs hatás mértékét mutatja meg a nemzetgazdaságokban. Az indikátorok egyrészről az üzleti K+F ráfordítások arányát, a szabadalmi bejelentéseket, és a tudományos élet hazai-, és nemzetközi publikációinak arányát mutatják meg, amelyekhez másrészről a KKV szektor termék és szolgáltatás innovációja, valamint a marketing és szervezeti innovációk társulnak. Erre a komponensre jellemző továbbá az innovatív társulásokban való foglalkoztatottsági arány, valamint a tudás intenzív foglalkoztatottsági arány is. A külföldi szabadalom bevételek aránya is megjelenik ebben a komponensben, amelyhez a GCI mutatók közül a versenyképességi előnyök indikátora társul. Ez utóbbi egyben azt is jelenti, hogy az innovációs mutatók üzleti szférával való együttállása, és a versenyképességi előnyökkel való kapcsolat egymással kölcsönhatásban van.

Ezek alapján kijelenthető, hogy az első és második komponensek együttmozgó klaszter értékei, az innovációs folyamatok és a versenyképességi fejlettség kölcsönhatását jelentik majd a későbbiekben, az eltérőek pedig ennek a kölcsönhatásnak a hiányát.

\section{Innováció és versenyképesség vezérelt nemzetgazdaság komponens (III. komponens)}

A harmadik komponensben vegyesen IUS és GCI indikátorok is vannak. Ebben a fókomponensben a nemzetgazdaság mérete és annak import-export hatásai jelennek meg a versenyképesség szempontjából. A felsőoktatás és szakképzés, a nem EU övezetből jött doktoranduszok arányát kifejező indikátorral van kapcsolatban, a vásárlói technikák versenyképessége mellett pedig a komponens több másik, az innováció vezérelt gazdaságokhoz kapcsolódó indikátort is tartalmaz. Ez utóbbiak lényegében az üzleti kifinomultságot, az üzleti környezetet, és a vállalati minőséget jelentik. A komponens tehát kifejezi az adott nemzetgazdaság nemzetközi integráltságának mértékét. 
www. metszetek.unideb.hu

TEMATIKUS TANULMÁNYOK - Menedzsment: vezetők, vezetés és munkavállalók

Nemzetgazdaság infrastruktúrájának minőségét kifejező komponens

(IV. komponens)

A negyedik komponens a magyarázóérték közel 10\%-át adja. Ez a komponens a nemzetgazdasági mechanizmusok közül az infrastruktúra kiterjedtségét, a telekommunikációs lefedettséget, és az országokra jellemző energiabiztonságot fejezi ki. Ezen kívül ez a komponens az importtermékek egészségügyi szabványrendszerének alaposságát magyarázza, valamint a biztonságpolitikai hatékonyság kifinomultságát mind a terrorizmus, mind pedig a bűnözés visszaszorítása szempontjából.

\section{Konklúzió}

Az innovációs és versenyképességi indikátorok, az Európai Unió tagállamaira vonatkozóan vegyesen alakítanak ki olyan főkomponenseket, amelyeknek innovációs és versenyképességi összetevőik egyaránt vannak. Tehát makroszinten az innovációs teljesítmény és a versenyképesség egymástól el nem választhatók. Természetesen külön elemzést igényel e két indikátorcsoport időbeli kapcsolata, illetve egymás kölcsönös befolyásolásának jellege. Ehhez a jelen vizsgálatot hosszabb idősorra kívánom kiterjeszteni.

Kialakított főkomponensek:

- Tényező és hatékonyságvezérelt versenyképességi komponens,

- versenyképességet támogató innovációs output komponens,

- innováció és versenyképesség vezérelt nemzetgazdaság komponens,

- nemzetgazdaság infrastruktúrájának minőségét kifejező komponens.

\subsection{KLASZTERELEMZÉS}

Az adatbázis elemzés első fázisának befejezése után, négy jól meghatározott főkomponenst kaptunk. A kapott főkomponensek bevonásával elvégzett nem hierarchikus klaszteranalízis eredménye 5 csoport lett.

\section{Elmaradók csoportja (3-as klaszter) (Bulgária, Lengyelország, Románia)}

Ebbe a csoportba 3 ország tartozik. Ezek az országok minden téren messze az átlag alatt teljesítenek. A szakképzés, az árupiac, a munkaerő optimalizálására már ugyan vannak törekvések ezekben a nemzetállamokban, azonban az ezt támogató K+F ráfordítások, szabadalmi bejelentések, a termék-, szolgáltatás-, marketing- és szervezeti innovációk még elmaradnak a várt színvonaltól és a versenyképességi mutatók javulásához képest jóval gyengébb tendenciákat mutatnak. A méretgazdaság növekedésének, és az export-import arány megváltozásának szintén nem kedvez a gazda- 


\section{TEMATIKUS TANULMÁNYOK - Menedzsment: vezetők, vezetés és munkavállalók}

sági környezet, a szemléletváltás hiányában pedig az üzleti kifinomultság, és az üzleti környezet fejlesztése is visszamaradott. Ezekben az országokban magas a korrupció és a bűnözés mértéke, az infrastruktúra és telekommunikációs rendszer pedig erős fejlesztésre szorul.

Elszakadók csoportja (1-es klaszter) (Cseh Köztársaság, Horvátország,

Magyarország, Litvánia, Lettország, Portugália, Szlovénia, Szlovákia)

Az Elszakadók csoportjába 8 ország tartozik. Erre a csoportra jellemző az intézményrendszer és az üzleti szféra kooperációjának hiánya, ami alapján a gazdaság számos terültén fejlesztésekre van szükség. A felsőfokú végzettségűek aránya elmarad a várt szinttől, az üzleti kifinomultság ezért lemarad a kívánatostól. Ezekben a nemzetgazdaságokban alacsony az üzleti szféra versenyképességére gyakorolt innovációs hatás. A K+F fejlesztések, a megújítási, és szabadalmi törekvések szintén nagyobb támogatóapparátust igényelnének. Ugyan jellemző az innováció és versenyképesség együttállása, azonban mindkét téren negatív mértékben mozognak együtt ezek a gazdaságra ható tényezők.

A nemzetgazdaság mérete, az import és export forgalom növelése szintén elmarad a várt szinttől, az üzleti környezet fejletlen. Ezekben az országokban szigorú szabályozás van, az energiabiztonság, az import termékekre vonatkozó szabályozás szigorú előírásokat követ, valamint a bűnözés felszámolására fordított éves büdzsé is magas.

Üzleti szféra kifinomultságának csoportja (4-es klaszter) (Belgium, Németország, Spanyolország, Franciaország, Olaszország, Egyesült Királyság)

Ezekre a nemzetgazdaságokra jellemző a versenyképességi és innovációs tendenciák együttállása, azonban ezek fejlettsége még nem elégséges. Ezekben az országokban gazdasági paradigmaváltás van készülőben, aminek azonban még az első fázisában vannak a csoportba tartozó országok. Ezek a nemzetgazdaságok nagymértékben fejlődnek, import igényük és export teljesítményük jellemzően magas. A gazdaság háttértámogató innovációs rendszere ugyan még fejletlen, mégis a vásárlói technikák, az üzleti kifinomultság és a vállalati minőség szempontjából több szinten fejlettek ezek a nemzetállamok. A gazdaságoknak tehát a saját innovációs táptalaja még nem épült ki, ezért versenyképesség szempontjából ezekre a nemzetgazdaságokra jellemző a piaci hatékonyság visszamaradottsága. A biztonságpolitika és a telekommunikációs fejlettség szempontjából ezek az országok jobb adottsággal rendelkeznek a versenyképességi komponenshez képest, azonban ezen a területen is átlag alatti a teljesítményük. 


\section{TEMATIKUS TANULMÁNYOK - Menedzsment: vezetők, vezetés és munkavállalók}

Tényező-, és hatékonyságvezetők csoportja (5-ös klaszter)

(Ausztria, Észtország, Finnország, Hollandia)

Ebbe a csoportba, a 2013-as adatok szerint 6 ország tartozott. Ezeknek az országoknak az infrastruktúrája már igen fejlett, a politikai intézményrendszer és az üzleti szféra összehangoltsága érzékelhetően kihat az adott országok versenyképességére. Ezek a nemzetállamok leginkább hatékonyságvezérelt gazdaságok, melyet versenyképes intézményrendszer támogat. A felsőfokú végzettségűek aránya magas, az üzleti környezet hálózatának minősége kiemelkedő. Az innovációs és versenyképességi indikátorok együttállása nem jellemzi ezeket az országokat, az innovációt támogató intézkedések viszont átlagon felüliek. Ezek az országok a piacnövekedés, az export-import arányok korlátai miatt azonban nem tudnak kiugró sikereket elérni, a vásárlói technikák, üzleti kifinomultság, és üzleti környezet szempontjából is, az országok átlag alatt teljesítenek. Ugyanakkor van bennük növekedési potenciál a kiépült infrastruktúra, és a fejlett telekommunikációs rendszer révén. A csoportba tartozó nemzetállamok tényező, és hatékonyságvezéreltek.

\section{Tudás-Innovátorok csoportja (2-es klaszter) (Dánia, Írország, Svédország)}

Ezekre az országokra olyan innovációs fejlettség a jellemző, mely támogatja a versenyképességet. Az innovációs hatás ugyan sokkal erőteljesebb mértékű, de a versenyképesség tekintetben is megfelelőek a nemzetállamok mutatói. A 2013-as adatok alapján még ezekben az országokban nem kellett a terrorizmus és bűnözés visszaszorítása érdekében komolyabb anyagi ráfordításokat áldozni. Ezekben a nemzetállamokban a legfejlettebbek a szabadalmi jogok, a szellemi tudásfelhalmozás, valamint a K+F fejlesztések, és a tudásalapú foglalkoztatottság.

\section{Klaszterelemzés konklúziója}

A csoportok árnyalt képet adtak az innováció és versenyképesség kettőssége szempontjából. Nehéz lenne válaszolni arra a kérdésre, hogy melyik csoporthoz kellene a többi csoportnak idomulnia, az adatok alapján pusztán csak arra van lehetőségem, hogy azt állítsam, hogy a szellemi tőkefelhalmozás szempontjából a Tudás-Innovátorok csoportja, a hatékony üzleti szféra szempontjából a Tényező-, és hatékonyságvezetők csoportja, az üzleti környezet minősége szempontjából pedig az Üzleti szféra kifinomultságának csoportja a legfejlettebb. Az Elmaradók csoportja sok innovációs-, és versenyképességi tényező szempontjából visszamaradott, az Elszakadók viszont ehhez képest már néhány szempontból elkezdtek konvergálni az átlag közeli értékekhez. 
www. metszetek.unideb.hu

\section{TEMATIKUS TANULMÁNYOK - Menedzsment: vezetők, vezetés és munkavállalók}

\section{3. Összegzés}

Az innovációs szakirodalom áttekintése során az a tapasztalat szűrhető le, hogy a tudós társadalomban még nem alakult ki egységes fogalomkör az innováció definiálását illetően. Számos kutató, eltérő módon értelmezi magát az innovációs folyamatot, és innovációs dimenziókat is, azonban az újítás gondolata általánosítható.

Az irodalmi áttekintés során kiderült, hogy számos kutató az innováció és a versenyképesség kapcsolatrendszerét vizsgálja, azok között kölcsönhatásokat feltételez. A cikkben éppen ezért egy innovációs, és egyben versenyképességi kutatás 2013-as adatokra vonatkozóan azt mutatja be, hogy valóban érdemes ezzel a hipotézissel kutatásokat lefolytatni.

Az elemzés jól definiált komponenseket (4 darab), és jól definiált csoportokat (5 darab) adott, amibe jól illeszkednek az Európai Unió vizsgált tagállamai.

Az eredmények alapján kijelenthető, hogy a jövőben hasonló innovációs és versenyképességi összehasonlító elemzéseknek is van relevanciája, ahol számos még megválaszolatlan kérdésre lehet választ találni az innovációs, és versenyképességi folyamatok vizsgálataival.

- Elmaradók csoportja: Bulgária, Lengyelország, Románia

- Elszakadók csoportja: Cseh Köztársaság, Horvátország, Magyarország, Litvánia, Lettország, Portugália, Szlovénia, Szlovákia

- Üzleti szféra kifinomultságának csoportja: Belgium, Németország, Spanyolország, Franciaország, Olaszország, Egyesült Királyság

- Tényező-, és hatékonyságvezetők csoportja: Ausztria, Észtország, Finnország, Hollandia

- Tudás-Innovátorok csoportja: Dánia, Írország, Svédország

Nyitott kérdések:

- Milyen innovációs és versenyképességi adottságai fejlődtek, illetve romlottak Magyarországnak a vizsgált időszakban?

- Milyen okokra vezethető vissza az Európai régió innovációs és versenyképességi differenciáltsága?

- Milyen jó gyakorlatot felmutató országok innovációs és versenyképességi stratégiáját lenne célszerú adaptálnia az elmaradó országoknak?

- Milyen más adatbázisok állnak rendelkezésre hasonló elemzések lebonyolítására? 
www. metszetek.unideb.hu

TEMATIKUS TANULMÁNYOK - Menedzsment: vezetők, vezetés és munkavállalók

\section{Irodalom}

Christensen, C. (2012): Disruptiv Innovation. Harvard Business School, Boston

Dinya László (2015a): Nonbusiness innovációk a gazdaságban. In: Kézirat, SZTEGTK, 1-17.

Dinya László (2015b): Nonbusiness innovációk és versenyképesség. In: EMOK XXI. Konferenciája, tanulmánykötet, 28. pp. 417-430.

Drucker, P. (1985): Innováció és vállalkozás az elméletben és a gyakorlatban. Park Kiadó, Budapest

Gerdesics Viktória - Pavluska Valéria (2013): Irodalomkutatás az innováció elfogadás-elméletekről In: Pécsi Tudományegyetem (letöltés helye: http://ktk.pte.hu/ sites/ktk.pte.hu/files/mellekletek/2016/01/gerdesics_pavluska_irodalomkutatas_az_innovacio_elfogadas-elmeletekrol_2013.pdf , utolsó letöltés ideje: 2018. 05. 11.)

IUS (2014): Innovation Union Scoreboard 2014. European Union. Belgium (letöltés helye: http://ec.europa.eu/enterprise/policies/innovation/files/ius/ius-2014_ en.pdf, letöltve: 2015. 03. 02.).

Kiss János (2013): Az innováció hatása a vállalati teljesítményre és versenyképességre. BCE Vállalatgazdasági Intézet Versenyképesség Kutató Központ, Budapest

Kovács Olivér (2014): Alapok a versenyképesség modern értelmezéséhez: Magyarország versenyképességének alakulása. ICEG Európai Központ, Budapest

Schumpeter, J. A. (1943): Capitalism, Socialism, Democracy. Harper, New York

Varga János (2015): Az értékteremtés lehetséges formái az innovációk innovációjának korszakában. In: Vállalkozásfejlesztés a XXI. században, 179-188.

World Economic Forum (2014): The Global Competitiveness Report 2014-2015. European Union, Genova (letöltés helye: http://www3.weforum.org/docs/WEF_ GlobalCompetitivenessReport_2014-15.pdf, letöltve: 2016. 04. 01.). 